\title{
Evaluation of Cereal-Legume Cropping on Striga Control and Maize Yield
}

\author{
Vivian Namutebi, Lukman Nagaya Mulumba and Jenipher Bisikwa \\ Department of Agricultural Production, College of Agricultural and Environmental Sciences, Makerere University, P.O. Box 7062, \\ Kampala, Uganda
}

\begin{abstract}
Striga hermonthica (Del.) Benth is ranked as the number one constraint to maize productivity in Eastern Uganda. The use of trap crops is one of the control measures suggested for farmers with limited resources in Striga infested areas. In this study the main focus was on the effectiveness of intercropping in reducing Striga infestation and hence overall land productivity. The major objective was to identify suitable legumes in the control of Striga. In order to achieve this, on-farm experiments were conducted in Tororo and Busia districts of Eastern Uganda where the effect of the legumes on the Striga prevalence was evaluated. Maize (Zea mays) was intercropped with common beans (Phaseolus vulgaris), soybean (Glycine max) and silver leaf desmodium (Desmodium uncinatum) with sole maize (Z. mays) as the control. Soybean, beans and desmodium decreased the infestation of Striga by $26 \%$, $40 \%$ and $72 \%$, respectively. There was a significant $(p<0.05)$ difference in the number of emerged Striga and maize yield attained by desmodium and the rest of the legumes. Desmodium was found to be the most effective of the legumes in the control of Striga.
\end{abstract}

Key words: Striga hermonthica (Del.) Benth, Zea mays, legumes, intercropping, Uganda.

\section{Introduction}

Food production in sub-Saharan Africa has remained constant for years yet the population is increasing [1]. The depletion of soil fertility mainly through soil mining combined with pests, weeds and diseases has greatly contributed to the low per capita food production in these areas. This has consequently led to poverty and food insecurity $[2,3]$. The parasitic weed Striga, is one of the major constraints to agriculture in the world [4]. Striga infested areas can lead to yield loses ranging from $40 \%$ to $100 \%$. The weed affects two thirds of all cropping land in Africa with an estimation of 300 million people being affected [5].

There are about 40 species of Striga, with 11 being economically important in agriculture. $S$. hermonthica, S. asiatica and $S$. gesnerioides are the most widespread. S. hermonthica and S. asiatica affect cereals, while $S$. gesneriodes affects legumes which include cowpea [6]. In Uganda the purple

Corresponding author: Vivian Namutebi, MSc, research fields: soil fertility management, intercropping and striga. flowered S. hermonthica (Del.) Benth is ranked as the number one constraint to maize, a major staple in eastern region [7]. Maize is the most affected as it is not native to Africa. Striga attaches itself to the host plant depriving it of nutrients, water and food made by the plant, this consequently leads to yield losses. A number of methods have been devised to control Striga. These include the use of agricultural inputs like fertilizers, herbicides, mechanical weeding, use of resistant cultivars and the use of trap crops [8]. However, the use of inputs is expensive for most of the farmers, while the resistant cultivars for maize are not easily accessible on the Ugandan market. The use of trap crop has been recommended for poor resource farmers [9]. These trap crops are potentially very important as a Striga control measure because they can stimulate the germination of Striga which will later die due to the absence of a host and improve soil fertility [10]. Some of the trap crops include sunflower, cotton and legumes.

The objective of this study was to determine the most suitable legume for Striga control. This was 
done by evaluating the effect of the selected legume trap crops on Striga prevalence and maize grain yield in Eastern Uganda. Commonly grown legumes like beans (Phaseolus vulgaris), and soybean (Glycine max) were compared against silver leaf desmodium (Desmodium uncinutum).

\section{Materials and Methods}

\subsection{Study Site}

The experiment was carried out in Eastern Uganda in Tororo and Busia districts. Tororo district lies between 1,097 $\mathrm{m}$ above sea level and 1,219 $\mathrm{m}$ above sea level, $00^{\circ} 41^{\prime} 34^{\prime \prime} \mathrm{N}$ and $34^{\circ} 10^{\prime} 52^{\prime \prime} \mathrm{E}$. Its average annual rainfall is approximately $1,450 \mathrm{~mm}$ while its average minimum and maximum temperatures are $16.2{ }^{\circ} \mathrm{C}$ and $28.7{ }^{\circ} \mathrm{C}$, respectively. The soils are predominantly sandy. It has a population of about 58,456 people of whom 54\% are females [11]. Busia district is located at the south east corner of Uganda, lying at $1,198 \mathrm{~m}$ above sea level, between $33^{\circ} 05^{\prime} \mathrm{E}$ $00^{\circ} 10^{\prime} \mathrm{N}$ and $34^{\circ} 01^{\prime} \mathrm{E} 00^{\circ} 35^{\prime} \mathrm{N}$. Busia's average annual rainfall is $1,200 \mathrm{~mm}$, with an average maximum and minimum temperatures at $32{ }^{\circ} \mathrm{C}$ and $15{ }^{\circ} \mathrm{C}$, respectively. It has a population of 42,596 people with $52 \%$ of the population being female $[12,13]$.

\subsection{Plot Layout and Data Collection}

Soybean, common beans and desmodium were intercropped with maize on Striga infested plots. Soybean and common beans are food crops while desmodium is a fodder crop. Some of the farmers especially in Tororo were practicing mixed farming. Desmodium was intercropped with maize at a ratio of 1:1 (one row of maize with one row of the other intercrop).

The plot size was $25 \mathrm{~m}^{2}$. Plots were $5 \mathrm{~m}$ by $5 \mathrm{~m}$. Maize was planted at a spacing of $75 \mathrm{~cm}$ by $60 \mathrm{~cm}$ after application of $60 \mathrm{~kg} \mathrm{~N}, 15 \mathrm{~kg} P$ and $30 \mathrm{~kg} \mathrm{~K}$ per hectare and a spacing of $1.5 \mathrm{~m}$ between the plots. The legumes were drilled in between maize rows. After three weeks soybean was then thinned at an intra-row spacing of $5 \mathrm{~cm}$ while beans were thinned to $15 \mathrm{~cm}$. Varieties included Longe 5 for maize, silver leaf for desmodium, Mak Soy 1N for soybean and K132 for beans.

The treatments were laid out in a completely randomized design with five replicates. Treatments included the following intercrops maize with soybean, maize with cowpeas, maize with common beans, maize with desmodium and sole maze as the control.

Plots were weeded every three weeks to avoid the increase in the soil seed bank (especially when the crops were flowering). During the 8th and 12th week after planting maize 10 plants were sampled in each treatment to assess the Striga incidence. The number of Striga plants within a radius of $15 \mathrm{~cm}$ from each of the 10 sampled plants in each treatment was counted. This was done by counting the number of maize crops infested by Striga. The Striga seed bank was determined according to Eplee and Norris [14] at Kenya Agricultural Research Institute, Kibos, Kenya. Yield and yield components of maize (the Stover weight), common beans, soybean were collected. All the maize plants in each experimental plot were harvested and grain yields converted were assessed per hectare. The data collected were analyzed using Genstat statistical package version 13. Using a 5\% probability level, the least significant difference (LSD) was used to determine differences among treatment means.

\section{Results}

\subsection{Striga Incidence}

The maize intercrops with soybeans, beans and desmodium significantly reduced the number of emerging Striga plants. There was a significant $(p<$ 0.05 ) difference among the intercrops and the sole maize as shown in Fig. 1. Although the maize-bean and maize-soybean intercrops reduced the Striga infestation by $26 \%$ and $40 \%$, respectively, there were no significant differences between them. The desmodium 
maize crop combination had the least number of emerging Striga plant with a decrease in infestation by $72 \%$.

\subsection{The Striga Seed Bank}

The crop combination of the maize with the legumes significantly $(p<0.05)$ reduced the number of Striga seeds in the soil as compared to the sole maize as seen in Fig. 2. Soybean, beans and desmodium intercrops with maize decreased the number of Striga seeds by $15 \%, 13 \%$ and $49 \%$. The maize desmodium intercrop significantly had the greatest effect compared to the soybean and bean intercrops with maize.

\subsection{The Maize Yield}

The yield of maize was significantly higher in the intercrops as compared to the mono cropped maize. Results shown in Fig. 3 indicate that soybean, beans and desmodium enhanced maize yields by $17 \%, 28 \%$ and $66 \%$, respectively, after the two seasons. The desmodium intercrop glaringly enhanced the yield of maize as compared to the rest of the legumes.

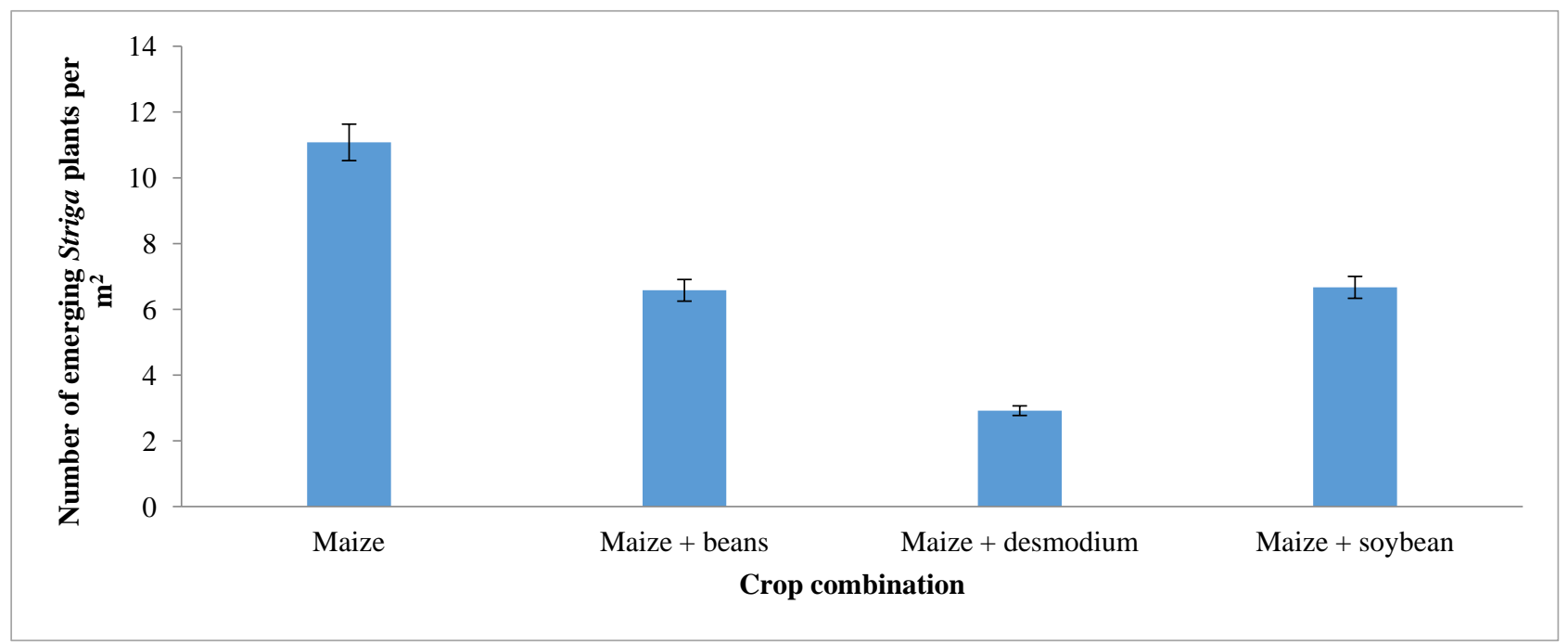

Fig. 1 Effect of the crop combination on the emerged Striga plants.

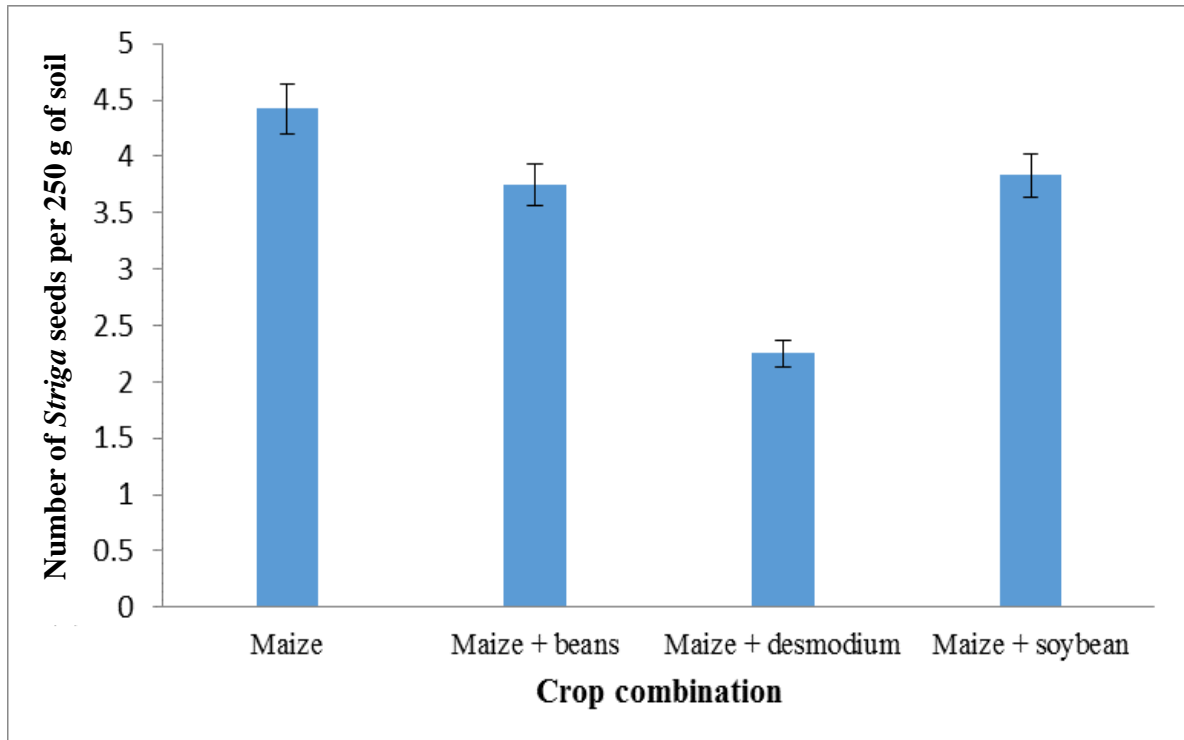

Fig. 2 The effect of the crop combination on the Striga seed bank. 


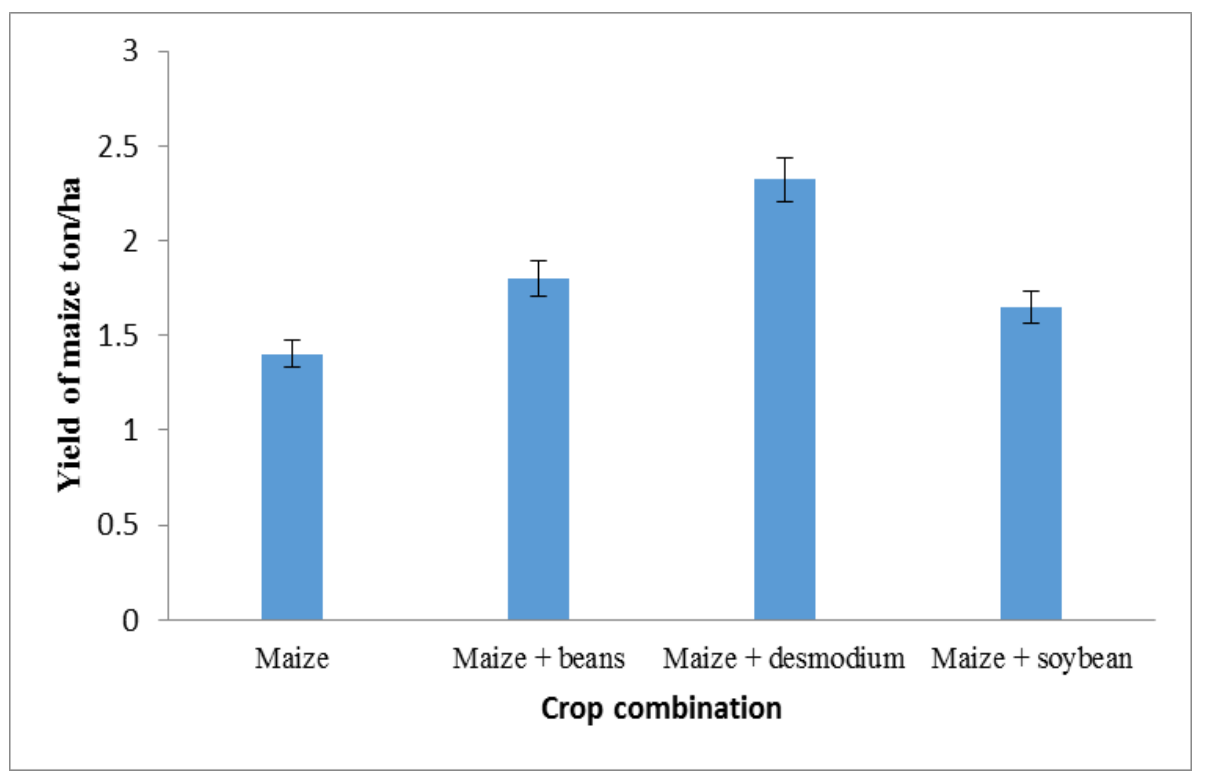

Fig. 3 The effect of crop combination on the yield of maize.

Table 1 Effect of previous crop on organic matter (OM), total soil nitrogen (N) and available phosphorus (P) in the soil.

\begin{tabular}{llll}
\hline Treatment & OM \% & Total N \% & Available P $(\mathrm{ppm})$ \\
\hline Maize & 3.4 & 0.24 & 4.69 \\
Maize + beans & 4.7 & 0.26 & 34.97 \\
Maize + desmodium & 5.4 & 0.27 & 98.66 \\
Maize + soybean & 5.0 & 0.22 & 23.53 \\
\hline
\end{tabular}

\section{Discussion}

\subsection{The Striga Incidence and Seed Bank}

The observed reduction in the number of emerged Striga in the intercrops as shown in Fig. 1 could be attributed to their trap crop ability. This is similar to findings by Khan [15]. These legumes are able to stimulate the germination of the Striga seeds but without the host crop, the germinated Striga dies a condition known as suicidal germination [16]. This suicidal germination eventually also contributes to the decrease of the seed bank. Maize being a host crop to Striga stimulates the germination and supports the growth of Striga and hence the high number of Striga plant emerging in the sole maize plot. The less numbers of emerging Striga plants in the intercrops as compared the sole maize can be ascribed to smothering effect of the legumes leading to low temperatures and higher humidity in the soil [17]. This soil condition suppresses Striga germination forcing the weed into wet dormancy [18]. The efficiency of the intercropped maize in reducing emerging Striga plants could also be attributed to the increased the organic matter (OM) hence increased soil fertility in the soil as seen in Table 1. The reduction of Striga infestation by the legumes can be ascribed to the nitrogen that is biologically fixed by the nitrogen fixing bacteria in the legumes [19]. Increase of nitrogen in the soil reduces the production of strigolactone [20], a precursor for Striga germination leading to low Striga infestation. Additionally, the ammonium form of nitrogen produced during decomposition of plant residues [20], has been found to suppress Striga. Intercropping maize with the legumes also enhanced biodiversity in the soil [21]. This may include microorganisms some of which may be natural enemies of Striga [22] like some species of fungi hence leading to the decrease of Striga [23]. This could eventually contribute to the decrease of the Striga seeds in the soil. 


\subsection{The Maize Yield}

With the suppression of the Striga growth there was increase in the yield of maize as shown in Fig. 3. The highest yield was in the maize desmodium intercropping. This is similar to findings of Khan et al. [17] who noted that desmodium was superior to other legumes in suppressing Striga. In addition to its high nitrogen content in the soil and smothering effect, the perennial nature of desmodium also played an important role in the control of Striga [17]. Desmodium can stay in field even after the maize is harvested. In this way it is able to prolong its effects (smothering and nitrogen fixation) in the soil.

\section{Conclusions}

Intercropping legumes with maize is advantageous in controlling Striga. This could be attributed to the smothering effect, increased OM and nitrogen in the soil. This consequently led to increase of maize grain yield. Among the legumes, desmodium was the most efficient legume in controlling Striga and had the highest yield of maize in the intercrop. It is therefore recommended that the small holder farmers incorporate this legume in order to improve maize yields in the Striga infested areas.

\section{Acknowledgment}

The authors are grateful to Alliance for a Green Revolution in Africa (AGRA) for funding this research.

\section{References}

[1] Sanchez, P. A. 2002. "Soil Fertility and Hunger in Africa." Science 107 (1): 41-54.

[2] Pender, J., Jagger, P., Nkonya, E., and Sserunkuuma, D. 2002. "Development Pathways and Land Management in Uganda: Causes and Implications." Presented at 2002 AAEA Annual Meeting, Long Beach, California.

[3] Bekunda, M. A., Nkonya, E., Mugendi, D., and Msaky, J. J. 2004. "Soil Fertility Status, Management and Research in East Africa." East African Journal of Rural Development 20 (1): 94-112.

[4] Atera, E. A., Itoh, K., and Onyango, J. C. 2011.
"Evaluation of Ecologies and Severity of Striga Weed on Rice in Sub-Saharan Africa." Agriculture and Biology Journal of North America 2: 752-60.

[5] Yonli, D., Traoré, H., Sérémé, P., Sankara, P., and Hess, D. E. 2012. "Integrated Management of Striga hermonthica (Del.) Benth in Sorghum Using Fusarium Inoculum, Host Plant Resistance and Intercropping." Journal of Applied Biosciences 53: 3734-41.

[6] Ejata, G. 2007. "The Striga Scourge in Africa: A Growing Pandemic." In Integrating New Technologies for Striga Control: Towards Ending the Witch-Hunt. London: World Scientific Publishing Co. Pte. Ltd., 3-4.

[7] African Agricultural Technology Foundation (AATF). 2009. Baseline Study of Smallholder Farmer in Striga-Infested Maize Growing Areas of Central Malawi. Nairobi, Kenya: African Agricultural Technology Foundation, ISBN 9966-775-07-2, 1-3.

[8] Kundra, A., Chemining'wa, G. N., and Onwonga, R. N. 2012. "Relationships between Agronomic Practices, Soil Chemical Characteristics and Striga Reproduction in Dryland Areas of Tanzania." Journal of Agricultural Science and Technology A 2: 1134-41.

[9] Kureh, I., Kamara, A. Y., and Tarfa, B. D. 2006. "Influence of Cereal-Legume Rotation on Striga Control and Maize Grain Yield in Farmers' Fields in the Northern Guinea Savanna of Nigeria." Journal of Agriculture and Rural Development in the Tropics and Subtropics 107 (1): 41-54.

[10] Odhiambo, J. A., Vanlauwe, B., Tabu, I. M., Kanampiu, F., and Khan, Z. 2011. "Effect of Intercropping Maize and Soybeans on Striga hermonthica Parasitism and Yield of Maize." Archives of Phytopathology and Plant Protection 44 (2): 158-67.

[11] Miiro, R., Kabuye, F., Jama, B. A., Musenero, E., Zake, J. Y. K., Nkwiine, C., Kakinda, M. J., Onyango, O., and Delve, R. J. 2004. "Early Farmer Evaluation of Integrated Nutrient Management Technologies in Eastern Uganda." In Managing Nutrient Cycles to Sustain Soil Fertility in Sub Saharan Africa, edited by Bationo, A. Nairobi, Kenya: Academy Science Publishers, 549-50.

[12] Kabuye, F. M., Waata, F., and Kigulu, D. 2003. "Voices of Poor Livestock Keepers in Lake Victoria Basin." In Proceedings of Voices of Poor Livestock Keepers, Bondo District, Kenya, ICRAF, VPLK Document 17.

[13] Uganda Bureau of Statistics, 2002. 2002 Uganda Population and Housing Census; Tororo District Report. Uganda Bureau of Statistics, Volume 24, 9-11.

[14] Eplee, R. E., and Norris, R. S. 1990. "Soil Sampling Collection Equipment and Equipment to Separate Seeds from Soil." In Witchweed Research and Control in the United States, edited by Sand, P. F., Eplee, R. E., and Westerbrooks, R. G. Champaign, IL: Weed Science 
Society of America, 136-40.

[15] Khan, Z. R., Hassanali, A., Overholt, W., Khamis, T. M., Hooper, A. M., Pickett, J. A., Wadhans, L. J., and Woodcook, C. M. 2002. "Control of Witchweed Striga hermonthica by Intercropping with Desmodium spp. and the Mechanism Defined as Allelopathic." Journal of Chemical Ecology 28: 1871-85.

[16] Traore, H., Yonli, D., Diallo, D., and Sereme, P., 2011. "Suicidal Germination of Striga hermonthica (Del.) Benth. by Cotton, Cowpea and Groundnut Genotypes in Burkina Faso." International Journal of Agricultural Research 6: 49-57.

[17] Khan, Z. R., Midega, C. A. O., Hassanali, A., Pickett, J. A., and Wadhams, L. J. 2007. "Assessment of Different Legumes for the Control of Striga hermonthica in Maize and Sorghum." Crop Sci. 47: 728-34.

[18] Odhiambo, G. D., and Aringa, E. S. 2001. "Effect of Intercropping Maize with Beans on Striga Incidence and Grain Yield." In Proceedings of the Seventh Eastern and Southern Regional Maize Conference, 183-6.

[19] Kureh, I., Chikoye, D., Emechebe, A. M., Hussaini, M. A., Kormawa, P., Schulz, S., Ellis-Jones, J., Franke, L., and Odunze, A. C. 2003. "Reduction of Striga hermonthica Parasitism on Maize Using Host Plant Resistance, Fertilization and Rotation with Legume Trap-Crops." African Crop Science Conference Proceedings 6: 167-71.

[20] Kabambe, V., Katunga, L., Kapewa, T., and Ngwira, A. R. 2008. "Screening Legumes for Integrated Management of Witchweeds (Alectra vogelii and Striga asiatica) in Malawi." World Journal of Agricultural Science 2 (4): 367-71.

[21] Khan, Z. R., and Pickett, J. A. 2004. "The 'Push-Pull' Strategy for Stemborer Management: A Case Study in Exploiting Biodiversity and Chemical Ecology." In Ecological Engineering for Pest Management: Advances in Habitat Manipulation for Arthropods, edited by Gurr, G. M., Wratten, S. D., and Altieri, M. A. Wallingford, Oxon: CABI Publishing, 155-64.

[22] Esilaba, A. O. 2006. Options for Striga Management in Kenya. Kenya Agricultural Research Institute (KARI) Technical Note No. 19, March 2006.

[23] Ijoyah, M. O. 2014. "Maize-Soybean Intercropping System: Effects on Striga Control, Grain Yields and Economic Productivity at Tarka, Benue State, Nigeria." International Letters of Natural Sciences 14: 69-75. 